\section{'Tiger' Fig}

\section{Charles E. Johnson ${ }^{\mathbf{1}, \mathbf{3}}$, Ed O'Rourke ${ }^{\mathbf{2}}$, and James E. Boudreaux ${ }^{1}$ Louisiana Agricultural Experiment Station, Louisiana State University Agricultural Center, 137 J C Miller Hall, Baton Rouge, LA 70803}

'Tiger' fig (Ficus carica L.) was developed by the Louisiana Agricultural Experiment Station (LAES) to provide a productive tree of good-quality fruit, which ripens during the traditional fig harvesting period. 'Tiger' is a common-type fig and the fifth cultivar released from the LAES fig breeding program that was initiated in the 1950 s to develop cultivars for the gulf south region (O'Rourke et al., 2004). 'Tiger' was evaluated in plantings at research stations located at The Burden Center, Baton Rouge, LA (long. $30^{\circ} 24^{\prime} 3^{\prime \prime} \mathrm{N}$, lat. $91^{\circ} 6^{\prime} 2^{\prime \prime} \mathrm{W}$ ) and at the Citrus Research Station at Port Sulfur, LA

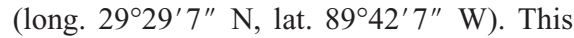
selection (57-13-121) was chosen for release because of superior fruiting characteristics.

\section{Parentage}

'Tiger' was selected from a group of seedlings from a cross of 'Celeste' and ' $\mathrm{C} 1$ '. ' $\mathrm{C} 1$ ' is a designation given a caprifig obtained from the University of California at Riverside in $\approx 1950$. The cross was made in 1957 and the selection made by Ed O'Rourke in 1961 and tested as L57-13-121. This selection was named 'Tiger' because the fruit has longitudinal stripes in the immature stage.

\section{Description}

Fruit. A comparison of fruit (syconium) characteristics of seven cultivars of commontype figs was made in the summer of 2008 using fruit from 8-year-old trees growing at Burden Research Center, Baton Rouge, LA (Table 1). Sixteen uniformly firm, ripe fruit were harvested from each tree in the canopy periphery $\approx 1.5 \mathrm{~m}$ from ground level. Plots were replicated three times with one tree per plot. Fruit were immediately taken to the laboratory for evaluation. Each replicate was weighed and divided into two lots for measuring soluble solids and color. Fruit from one lot of each cultivar were peeled and macerated. Approximately $3 \mathrm{~mL}$ of pulp was used to determine percent soluble solids using a bench-top refractometer. A $20-\mathrm{mL}$ sample of the macerated pulp was used to determine internal fruit color using a Minolta

Received for publication 15 Jan. 2010. Accepted for publication 18 Feb. 2010.

Louisiana State University Agricultural Center journal series 09-306-3829.

${ }^{1}$ Professors, School of Plant, Environmental and Soil Sciences.

${ }^{2}$ Distinguished Professor Emeritus.

${ }^{3}$ To whom reprint requests should be addressed; e-mail cejohnson@agctr.lsu.edu.
CM3500d spectrophotometer (Minolta Instrument Systems, Ramsey, NJ) standardized with a white calibration plate (Minolta CMA120). External fruit color was determined objectively by placing whole fruit from each cultivar on the eye lens of the spectrophotometer along the equator of each fruit. Four fruit were measured for external color at two points along the equator of each fruit and the L, a, and b measurements averaged (Table 2).

The fruit of 'Tiger' is persistent and does not require pollination. 'Tiger' produces good-quality fruit, 30 to $40 \mathrm{~mm}$ in diameter and large-sized brown fruit with a darker brown stripe visible on most fruit (Table 1). The tan to brown fruit of 'Tiger' has a slightly round distal end and tapers slightly toward the stem end with a short neck. The fruit has a partially closed eye (ostiole) on mature fruit. Internal color is yellow to gold with some red near the center when soft ripe (Fig. 1). Fruit ripen $\approx 5$ to $7 \mathrm{~d}$ after 'Celeste' or approximately the first week of July in Baton Rouge, LA. The main crop of 'Tiger' ripens

Table 1. Comparison of fruit characteristics of seven fig cultivars.

\begin{tabular}{lcc}
\hline Cultivar & Fruit $\mathrm{wt}^{\mathrm{z}}$ & Percent $\mathrm{SS}^{\mathrm{y}}$ \\
\hline Magnolia & $50.3 \mathrm{a}^{\mathrm{x}}$ & $21.2 \mathrm{a}$ \\
Champagne & $25.2 \mathrm{~b}$ & $18.1 \mathrm{~b}$ \\
Tiger & $27.5 \mathrm{~b}$ & $17.5 \mathrm{bc}$ \\
Alma & $35.7 \mathrm{~b}$ & $18.1 \mathrm{~b}$ \\
LSU Gold & $31.5 \mathrm{~b}$ & $15.2 \mathrm{c}$ \\
O'Rourke & $19.8 \mathrm{c}$ & $18.1 \mathrm{~b}$ \\
LSU Purple & $17.8 \mathrm{c}$ & $17.5 \mathrm{bc}$ \\
Hunt & $15.9 \mathrm{c}$ & $20.3 \mathrm{ab}$ \\
Celeste & $14.0 \mathrm{c}$ & $21.3 \mathrm{a}$ \\
\hline
\end{tabular}

${ }^{\mathrm{z}} \mathrm{Wt}$ is the mean of 16 fruit in grams.

yercent SS is percent soluble solids as measured by a refractometer.

${ }^{\mathrm{x}}$ Means in a column followed by a common letter are not significantly different at 0.05 level of probability according to Duncan's test. CM3500d spectrophotometer using standard CIE scale.

${ }^{\mathrm{z}} \mathrm{L}=$ degree of lightness $100=$ pure white, $0=$ black. according to Duncan's test. over a $15-\mathrm{d}$ period, which is comparable to 'Celeste' and 'Kadoto'.

Trees and foliage. Mature trees of 'Tiger' are $\approx 50 \%$ the size of comparable 'Celeste' trees. The growth habit is prostrate to drooping in the juvenile phase then growing semiupright when mature. The mature leaves of 'Tiger' are large palmate with five to seven distinct lobes. The primary lobe is spatulate and leaf margins serrated. The margin of the leaf on the basal lobes of 'Tiger' is slightly serrated.

Disease resistance. Eight-year-old trees of 'Tiger' fig cultivars with known degrees of susceptibility to late summer defoliation were grown in a research orchard at The Burden Center at Baton Rouge, LA. Field notes were recorded annually in late summer on the degree of defoliation of each tree. 'Tiger' is slightly more resistant to defoliation caused by the fig leaf rust [Cerotelium fici (E.J. Butler) Arthur] and leaf spot [Pseudocercospora fici (Heald \& F.A Wolf X. J. Liu \& Y. L. Guo) $=$ Cercospori fici] complex than 'Celeste'. Symptoms caused by the two pathogens often appear at the same time creating difficulty in determining which disease caused defoliation under field conditions.

\section{Culture}

'Tiger' is a common-type fig that is very productive and has performed well in grower trials and home orchards. The fruit are persistent and do not require pollination to set and mature. This selection has previously been unofficially named and propagated as 'Giant Celeste'; however, 'Giant Celeste' is

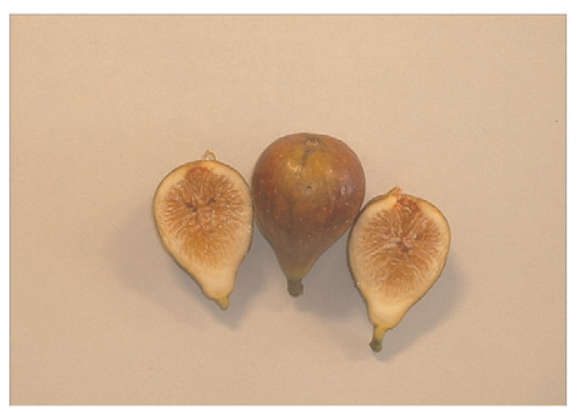

Fig. 1. Fruit of 'Tiger' (L57-13-121).

Table 2. Comparisons of internal and external colorimeter measurements of seven fig cultivars.

\begin{tabular}{|c|c|c|c|c|c|c|c|}
\hline \multirow[b]{3}{*}{ Cultivar } & \multirow{3}{*}{$\begin{array}{l}\text { Visual } \\
\text { color }\end{array}$} & \multicolumn{6}{|c|}{ Color values } \\
\hline & & \multicolumn{3}{|c|}{ External } & \multicolumn{3}{|c|}{ Internal } \\
\hline & & $\mathrm{L}^{\mathrm{z}}$ & $\mathrm{a}^{\mathrm{y}}$ & $\mathrm{b}^{\mathrm{x}}$ & $\mathrm{L}^{\mathrm{z}}$ & $\mathrm{a}^{\mathrm{y}}$ & $b^{x}$ \\
\hline Kadota & Yellow & $65.8 \mathrm{a}^{\mathrm{w}}$ & $2.1 \mathrm{c}$ & $51.6 \mathrm{a}$ & $52.3 \mathrm{a}$ & $7.2 \mathrm{~d}$ & $36.1 \mathrm{a}$ \\
\hline Champagne & Yellow & $64.4 \mathrm{a}$ & $2.0 \mathrm{c}$ & $50.6 \mathrm{a}$ & $50.7 \mathrm{a}$ & $6.5 \mathrm{~d}$ & $38.1 \mathrm{a}$ \\
\hline Hunt & Tan & $50.1 \mathrm{~b}$ & $12.2 \mathrm{ab}$ & $34.2 \mathrm{~b}$ & $54.3 \mathrm{a}$ & $12.9 \mathrm{c}$ & $35.1 \mathrm{a}$ \\
\hline Celeste & Tan & $49.3 \mathrm{~b}$ & $12.0 \mathrm{~b}$ & $16.4 \mathrm{~d}$ & $45.1 \mathrm{c}$ & $18.5 \mathrm{~b}$ & $24.4 \mathrm{c}$ \\
\hline O'Rourke & Tan & $46.0 \mathrm{~b}$ & $8.7 \mathrm{~b}$ & $23.7 \mathrm{c}$ & $51.4 \mathrm{~b}$ & $6.4 \mathrm{~d}$ & $34.8 \mathrm{a}$ \\
\hline Hardy Chicago & Black & $30.8 \mathrm{c}$ & $14.4 \mathrm{a}$ & $11.3 \mathrm{~d}$ & $45.0 \mathrm{c}$ & $22.9 \mathrm{a}$ & $24.7 \mathrm{c}$ \\
\hline LSU Purple & Purple & $24.7 \mathrm{~d}$ & $4.3 \mathrm{c}$ & $1.5 \mathrm{e}$ & $48.2 \mathrm{~b}$ & $11.1 \mathrm{c}$ & $28.9 \mathrm{~b}$ \\
\hline
\end{tabular}

External measurements are the mean values from 16 uniformly ripe fruit. Color was measured by a Minolta

$\mathrm{y}_{\mathrm{a}}=$ measurement of green to red on a scale of -80 to $100,-80=$ green, and $100=$ red.

${ }^{\mathrm{x}} \mathrm{b}=$ measurement of yellow to blue on a scale of -80 to $70,-80=$ blue, and $70=$ yellow.

${ }^{w}$ Means in a column followed by a common letter are not significantly different at 0.05 level of probability 
not necessarily the same as 'Tiger'. 'Tiger' is different from currently recommended fig cultivars and should offer a unique blend of color and size for pick-your-own, farmers' markets, and local markets. This cultivar produces large, good-quality fruit for marketing considerations (Pyzner, 2005) and complements current recommended varieties by increasing the diversity of fruit types. Fruit of all currently recommended cultivars of figs will split and crack to some degree during the ripening stage when ex- cessive moisture is present. Notations on deep radial cracks radiating from the ostiole of 'Tiger' 1 to $3 \mathrm{~d}$ after heavy rain events have been made. Field ratings indicate that 'Tiger' has a greater tendency for radial cracks when ripe than 'Celeste'.

\section{Availability}

The LSU AgCenter does not have nursery trees of 'Tiger' available. Limited quantities of dormant cuttings are available from C.E. Johnson for research.

\section{Literature Cited}

O'Rourke, E., C.E. Johnson, J.E. Boudreaux, and W. Bourgeois. 2004. LSU Gold, Fig. HortScience 40:486-487

Pyzner, J. 2005. Figs for commercial and home orchards in Louisiana. Louisiana State University Agricultural Center publication 1529 . 